\title{
Soil properties and subsoil constraints of urban and peri-urban agriculture within Mahikeng city in the North West Province (South Africa)
}

\author{
Simeon Albert Materechera ${ }^{1}$
}

Received: 31 January 2016/Accepted: 20 September 2016/Published online: 17 October 2016

(C) The Author(s) 2016. This article is published with open access at Springerlink.com

\begin{abstract}
Purpose Urban and peri-urban agriculture is becoming increasingly important as a source of income and food for the urban population in South Africa. While most studies on urban agriculture have focused their attention on surface soils, there is dearth of information regarding subsoil properties. This study examined properties of subsoil horizons that may impede root growth and productivity of crops under urban agriculture. Materials and methods The properties of topsoil $(0-20 \mathrm{~cm})$ and subsoil horizons $(20-40 \mathrm{~cm})$ of four profiles from plots within the city of Mahikeng $\left(25^{\circ} 48^{\prime} \mathrm{S}\right.$ and $\left.25^{\circ} 38^{\prime} \mathrm{E}\right)$ were examined to determine the nature of subsoil constraints that can limit root growth and crop productivity. The plots were selected in an area extending through four residential suburbs of the city, and two plots with a long history of cultivation were purposely selected from each suburb to represent the main cropping systems and soil types. Soil physical (penetrometer resistance, bulk density, hydraulic conductivity), chemical ( $\mathrm{pH}$, exchangeable $\mathrm{Ca}, \mathrm{Mg}, \mathrm{K}, \mathrm{Na}$, phosphorus and boron) and biological (root growth, organic carbon, microbial biomass, enzyme activity) properties were measured in the profiles.

Results and discussion Even though there was a large variability between profiles, the results revealed high bulk density (mean $2.06 \mathrm{Mg} \mathrm{m}^{-3}$ ) at the top of the subsoil for all the profiles. The corresponding mean penetrometer resistance was
\end{abstract}

Responsible editor: Christina Siebe Grabach

Simeon Albert Materechera

albert.materechera@nwu.ac.za

1 Indigenous Knowledge Systems (IKS) Centre, Faculty of Agriculture, Science and Technology, North-West University (Mahikeng Campus), P/B X2046, Mmabatho 2735, South Africa
1.89 MPa implying high mechanical resistance to root growth in this layer. The hydraulic conductivities at saturation were below $12 \mathrm{~mm} \mathrm{~h}^{-1}$ suggesting low drainage which may result in perched water table and waterlogging leading to depleted oxygen in the root zone. The $\mathrm{pH}$ in all the profiles was slightly acid to moderate alkaline (6.1-8.3, in water), and low levels of plant available boron (B) were found in the subsoil layers. Most of the profiles had extreme values of physical properties that would constrain root growth. All the subsoil layers had significantly $(p<0.05)$ lower root growth, organic carbon, microbial biomass and enzyme activity.

Conclusions It was concluded that subsoil constraints to root growth appear to be widespread in profiles of soils used for urban and peri-urban agriculture in the city of Mahikeng. Given that studying and ameliorating subsoil constraints is difficult, time-consuming and expensive, it is recommended that periodic deep ploughing and inclusion of plants with roots which are tolerant or resistant to these conditions be considered as part of routine soil management practice in plots used for urban agriculture.

Keywords Ferralsols · Physical · Chemical and biological soil properties $\cdot$ Rooting $\cdot$ Subsoil constraints $\cdot$ Urban agriculture

\section{Introduction}

The physical, chemical and biological properties of farming soils largely determine the potential agricultural productivity and sustainability of any farming system (Gliessman 1990). Considerable attention has in the past been directed towards the surface (plough) layer due to its variable water status and enrichment with soil nutrients and organic matter (Altieri 2002). Consequently, relatively less knowledge exists on the properties and soil conditions of horizons beneath the cultivated layer 
(Matson et al. 2007). Evidence is however available which suggests that a diverse range of single or multiple constraints do exist in subsoils which can seriously limit root growth, nutrient and water uptake, productivity and farm income (Graham et al. 1992; Nuttall et al. 2004; Lisson et al. 2007). Subsoil constraints are chemical, physical or biological properties in the subsoil that limit the ability of plants to utilize soil water and nutrient resources or otherwise have a detrimental effect on plant growth.

These subsoil constraints include boron toxicity (Adcock et al. 2007), contamination with resistant herbicides (Jayawardane and Chan 1994), sodicity and salinity, acidity (O'Leary et al. 2004; Dang et al. 2010; Zhang et al. 2006), nutrient deficiency and toxicity (Yunusa and Newton 2003; MacEwan et al. 2010), compaction (Lisson et al. 2007; Dang et al. 2010), low permeability and water logging (Kirkegaard et al. 2006; Swan et al. 2011), low organic matter content and activity of beneficial soil biota (Scott et al. 1997; Mead et al. 2005). Several of these constraints may occur together in some soils (Dang et al. 2006, 2010). The hostile subsoils restrict the movement of air and water and limit root growth, leading to waterlogging, variable rooting depth and poor water use efficiency (McDonald et al. 2012). Due to these constraints, the yields of dryland crops may only reach $50 \%$ of their water-limited potential (Dang et al. 2010). Subsoil degradation is increasingly being recognized as a serious limitation to achieving sustainable crop production on a range of soil types (Horn 2000).

The identification of the most limiting constraint and its interaction with other factors is a first step to plan for sustainable site-specific resource management. Adcock et al. (2007) have highlighted the difficulties associated with identifying the impact and effect of any single subsoil constraint to crop production and suggested that this limits our ability to develop targeted solutions designed to overcome these constraints. They further indicated that the task is complicated by spatial and temporal variability of soil physicochemical properties and nutrient availability, as well as other factors such as disease and drought stress. Nevertheless, these authors acknowledge the importance of identifying particular subsoil constraints to crop production in an ecosystem and consider this to be critical in the development of potential management solutions for such soils. It is well known that most South African soils provide a hostile environment for growth of roots but that these limitations are markedly reduced in surface horizons by application of organic and inorganic fertilizers, irrigation and tillage (ARC-ISCW 2004; Danie et al. 2004; DAFF 2011). The disk plough is used in most of the sites used for this study. Limited evidence is available which shows that subsoil constraints exist in most soils used for cropping in urban areas of South Africa (Farina and
Channon 1988; Farina et al. 1998; Materechera 2009; Materechera 2011).

According to Fey (2010), Hutton form soils are the most common soil type across South Africa's cereal environments and the subsoils of many of these soils often provide a hostile environment because of their high bulk density and low permeability to both air and water. Such properties are sometimes accompanied by sodicity, high salt concentrations and low nutrient status (Thompson 1986). Thompson (1986) has indicated that the presence of sodic conditions, the nature of the clay mineralogy and the soil structure of the B horizon appear to be the principal factors which correlate with or determine the hydrology of Hutton soils. While many subsoil problems in Hutton soils are associated with the slow permeability of the upper B horizon and consequent seasonal waterlogging, both accelerated acidification and sodicity have also become an increasing problem in some cropping systems (Thompson 1986). Many Hutton soils also display hardsetting properties which can extend into the subsoil horizons in some soils (Lambrechts and MacVicar 2004). Hardsetting is a primarily physical phenomenon which results from a combination of packing materials in a porphyric fabric, limited biological activity, low organic matter content and high bulk density (Mullins et al. 1990). Furthermore, most of these Hutton soils are highly weathered resulting in low levels of plant available nutrients including phosphorus, sulphur, nitrogen and micronutrients (Lambrechts and MacVicar 2004).

The urban growth rate in Africa, of $4.5 \%$ per annum, is the highest in the world, and it is estimated that $63 \%$ of Africa's urban population presently live in cities that have less than one million inhabitants (Mail and Guardian 2016). Food production in and around cities is an integral part of the urban fabric in much of the sub-Saharan Africa where it provides up to $20 \%$ of the food (Van den Berg and Van Veenhuizen 2005). Mahikeng is the capital city of the North West Province of South Africa with a population growing at a rate of $4.3 \%$ (Stats SA 2016). According to the Mahikeng Local Municipality (2013), the extent of urban agriculture has been increasing since 1994 when the country became a democracy. Although some studies have been conducted on the soils used for urban and peri-urban agriculture around the city of Mahikeng (Materechera and Gaobope 2007; Materechera 2009; Materechera 2011; Materechera 2014), there is generally a lack of spatial data on subsoil constraints that may impede and/or limit root growth and the productivity of urban agriculture, not only within the city of Mahikeng, but South Africa in general. As suggested by Zhang et al. (2006), the key towards realizing potential yields would be to gain a better understanding of subsoil layers and their limitations, then develop options to manage them practically and economically. 
There is very limited work done in subsoil layers in South Africa despite the fact that elsewhere, the subsoil layer has been shown to have significant interactions with root growth and crop performance (O'Leary et al. 2004; Dang et al. 2006; Nuttall and Armstrong 2010; McDonald et al. 2012).

Soil compaction caused by the passage of vehicular traffic, implements and draft animals has long been recognized as a worldwide soil degradation problem involved in limiting yields of agricultural, horticultural and forestry crops (Soane and Van Ouwerkerk 1994). As the contribution of urban and peri-urban agriculture to food security increases across the world (Mail and Guardian 2016), a better understanding of subsoils and their limitations, both spatially across the landscape and within the profile, is key towards developing options for better economic and environmentally sustainable management of these soils and realize their potential yields.

This study is exploratory in that it tries to establish how urban agriculture is influenced by soil properties in the subsoil horizons. Such studies are valuable not only in understanding soil properties but also in using the properties as a guide to land use and management especially with regards to irrigation, tillage and fertilization of soils used for urban agriculture. Opportunities exist for the global exchange of ideas and results with farmers, researchers and extension workers involved with crop production. The aim of this study was therefore to assess the occurrence of major subsoil constraints that may impede root growth and limit productivity of crops under urban agriculture in the city of Mahikeng of the North West Province in South Africa.

\section{Sites, material and methods}

\subsection{Description of study area and selection of plots}

The plots used for the study were located within $5 \mathrm{~km}$ of the city of Mahikeng $\left(25^{\circ} 48^{\prime} \mathrm{S}, 25^{\circ} 38^{\prime} \mathrm{E}\right)$ in the North West Province, South Africa. Mahikeng has a typical semi-arid tropical savannah climate with a mean annual summer rainfall of $571 \mathrm{~mm}$. The rainfall is unreliable and is highly variable $(\mathrm{CV}=31 \%)$ in both temporal and spatial distribution. The annual average evaporation of the area is $2201 \mathrm{~mm}$ (Mahikeng Local Municipality 2013). The mean monthly minimum and maximum temperatures vary from $4.0^{\circ} \mathrm{C}$ in July to $17.1^{\circ} \mathrm{C}$ in January and $20.4{ }^{\circ} \mathrm{C}$ in July to $29.7^{\circ} \mathrm{C}$ in February respectively. The municipal area slopes from $1410 \mathrm{~m}$ asl in the east to $1210 \mathrm{~m}$ asl in the west (Mahikeng Local Municipality 2013).

Four profiles were selected and examined for each residential area as shown in Fig. 1, representing key management options used by urban agriculture farmers in the city of Mahikeng. Plots were selected to reflect representative cropping histories and systems, irrigation, tillage and nutrient supply practices employed by the practitioners of urban agriculture in the city. Swelling, cracking and high-activity clay soils (vertic soils) were purposely avoided for the study.

\subsection{Description of the soil under study}

The texture of the surface $(0-20 \mathrm{~cm})$ soil at all the sites is sandy loam and is classified as a Hutton form (Soil Classification Working Group 1991) or Rhodic Ferralsol (IUSS Working Group WRB 2015) or Chromic Luvisol (FAO-ISS-ISRIC 1998). It is a red or yellow-brown soil with an orthic A horizon and a uniformly coloured red or yellow-brown apedal B or red structured B (oxidic soils) whose clay mineralogy is predominated by kaolinite and appreciable amounts of crystalline sesquioxides (Fey 2010). According to Fey (2010), the term 'apedal' refers to a structure which shows no planes of natural cleavage or lack of occurrence of individual natural soil aggregates or peds. Oxidic soils are widely distributed in South Africa with the Hutton form as the most commonly used (Fey 2010).

\subsection{Characteristics of the urban agriculture farmers in the study}

Table 1 shows that the sizes of plots varied from 0.16 to 0.53 ha (mean 0.34 ha) with most plots located in peri-urban areas of the city. The average length of time the plots have been cultivated for urban agriculture is 24 years (range 1731 years) although some have been over 30 years. This is consistent with the political history of the country when after attaining democracy in 1994, most black people started to engage in agriculture. Vegetables (cabbage, spinach, onion) were the major crops grown on all plots with maize, sorghum and beans grown in summer. Crops were grown mostly on ridges and flat beds. Hand tools were mostly used to till the land and weeding while some farmers hired tractors during land preparation. Sprinkler irrigation was most commonly used, and animal manure was used to supply nutrients especially to vegetables.

\subsection{Soil sampling and analyses}

For each selected plot, a $1-\mathrm{m}^{2}$ zone was earmarked around the centre during the period March to November 2014. A trench $100 \times 30 \times 50 \mathrm{~cm}$ was dug across the zone, and soil samples from the topsoil $(0-20 \mathrm{~cm})$ and subsoil $(20$ $40 \mathrm{~cm}$ ) layers were collected according to the scheme of Beater (1962). Subsoil was defined as all material immediately below the cultivated layer and/or A1 horizons, 


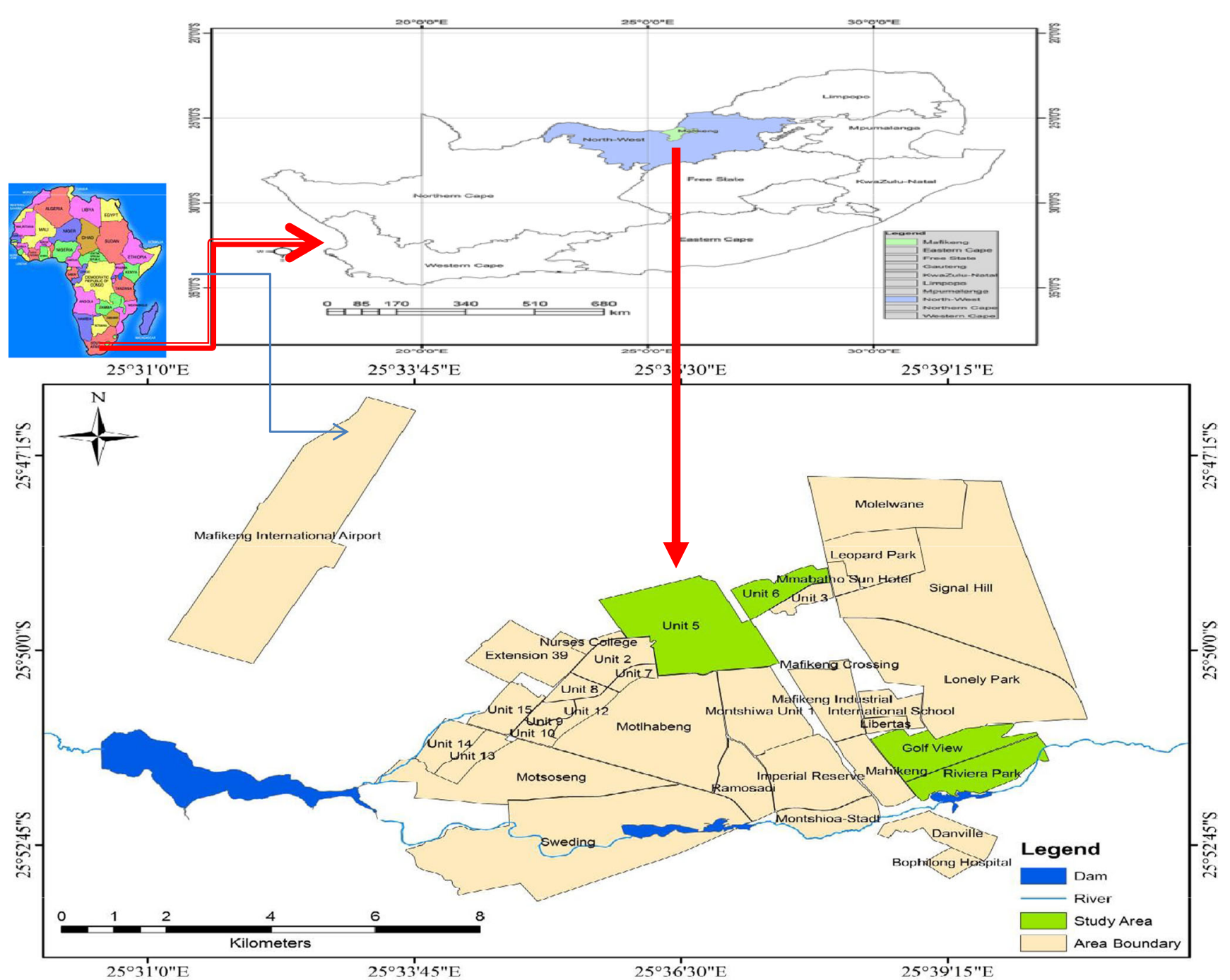

Fig. 1 Map of the city of Mahikeng showing the location of the study sites

Table 1 Characteristics and management history of the study plots

\begin{tabular}{lllll}
\hline Characteristic & Unit 5 & Unit 6 & Golf view & Reviera Park \\
\hline Length (years) & 31 & 17 & 27 & $19(23.5 \pm 6.6)$ \\
Plot size (Ha) & 0.23 & 0.16 & 0.53 & $0.45(0.34 \pm .34)$ \\
Texture & $\mathrm{SL}$ & $\mathrm{SL}$ & $\mathrm{SL}$ & $\mathrm{SL}$ \\
Colour & $2.5 \mathrm{YR} 3 / 2$ & $10 \mathrm{YR} 3 / 2$ & 10 YR4/3 & 7.5 YR3/2 \\
PSD (S: Si: C) & $40.9: 43.8: 15.3$ & $49.2: 39.9: 10.9$ & $53.4: 36.6: 10.0$ & $51.1: 37.6: 11.3$ \\
Main crops & Vegetable/sorghum & Maize/vegetables & Vegetable/bean/maize & Vegetables/maize \\
Seedbed type & Raised beds & Ridges/flat & Flat & Flat \\
Implements used & Hand & Hand & Tractor/hand & Hand \\
Weed control & Hand/chemical & Hand & Hand/chemical & Hand \\
Irrigation & Sprinkler & Pipe/sprinkler & Furrow & Basin/sprinkler \\
Nutrient sources & Fertilizer/manure & Manure/fertilizer & Fertilizer & Manure/fertilizer \\
\hline
\end{tabular}

Values in brackets represents Mean $\pm \mathrm{SD}$

PSD particle size distribution of topsoil fractionated according to the method of Day (1965) 
which in most farming systems in South Africa do not extend below $20 \mathrm{~cm}$ (FSSA 2003). For each layer, four subsamples were scrapped from the face (wall) of the trench with a small trowel and bulked to obtain a representative composite sample. A field-moist subsample was sieved $(<2 \mathrm{~mm})$, transported in airtight plastic bags placed in cooler boxes and later stored in a refrigerator for not more than $72 \mathrm{~h}$ before conducting soil microbial biomass and enzyme activity analyses (Haynes and Graham 2004). The rest of the sample was air-dried and passed through a 2 -mm sieve, and about $2.5 \mathrm{~kg}$ soil was kept in airtight plastic bags and used for the analyses of chemical properties and organic carbon.

\subsubsection{Physical properties}

Soil penetrometer resistance was measured in each plot using a stainless steel hand-operated soil cone penetrometer (model ASAE S313.2) with a dial gauge conical probe of $30^{\circ}$ and base diameter of $12 \mathrm{~mm}$ (Geotron Systems Pty Ltd). The penetrometer point was pushed into the soil at a constant rate, and the unconfined compressive strength was read. Thirty random penetrations were made within each plot by recording cone resistance at $5.0-\mathrm{cm}$ increments to a depth of $50 \mathrm{~cm}$ from the surface.

Soil bulk density in each layer was determined using the core method (Blake and Hartge 1986). The stability of aggregates in water was determined using initially air-dried aggregates (2-4 mm diameter) in the wet sieving technique of Yoder (1936). The sieve stack was oscillated through an amplitude of $3.5 \mathrm{~cm}$ at the rate of $25 \mathrm{~min}^{-1}$ for $3 \mathrm{~min}$. Aggregate stability was expressed as the proportion of the $>2-\mathrm{mm}$ fraction stable to the wet sieving treatment. The sorptivity of water into the soil was determined as the stabilized infiltration rate using the CSIRO disc permeameter (Perroux and White 1988). The surface of the land was cleared, and a disc permeameter was used on four randomly selected positions within each plot under ponded conditions $(0.05 \mathrm{kPa})$ and at a water supply pressure of about $-0.1 \mathrm{kPa}$.

\subsubsection{Chemical and biological properties}

Soil $\mathrm{pH}$ was determined using the glass electrode in 1:2.5 soil/water suspension following equilibration for $16 \mathrm{~h}$ (FSSA 2003). Exchangeable $\mathrm{K}, \mathrm{Ca}, \mathrm{Mg}$ and $\mathrm{Na}$ were extracted with $1 \mathrm{~N}$ ammonium acetate (The Non-Affiliated Soil Analysis Work Committee 1990) and determined by atomic adsorption $(\mathrm{K}, \mathrm{Ca}, \mathrm{Mg})$ and atomic emission spectrophotometry $(\mathrm{Na})$. Available phosphorus $(\mathrm{P})$ was determined using the Bray 1 method (Bray and Kurtz 1945). Boron (B) was extracted with the warm water reflux extraction procedure, and the $\mathrm{B}$ content of the extract was determined calorimetrically according to the method described by Jackson (1964).
Organic carbon was determined using the dichromate wet oxidation method (Okalebo et al. 1993). Microbial biomass C $\left(\mathrm{C}_{\text {mic }}\right)$ was estimated based on the difference between organic carbon extracted with $0.5 \mathrm{M} \mathrm{K}_{2} \mathrm{SO}_{4}$ from vacuum chloroformfumigated and unfumigated soil samples (Vance et al. 1987) using a $\mathrm{K}_{\mathrm{c}}$ factor of 0.38 (Brookes et al. 1985). Four replicate fresh samples (about $20 \mathrm{~g} \mathrm{dw}$ ) were analysed. The assay of the activity of protease enzyme was based on the release and quantitative determination of the product in a reaction mixture after the soil samples were incubated with a substrate and buffer solution (Tabatabai 1994). This enzyme was chosen because it plays a central role in C, N, S and P cycling in soils (Tabatabai 1994). Enzyme activity was expressed as micromoles of product released per gram of soil per hour (AcostaMartinez et al. 2003).

\subsubsection{Root length density}

Roots in each soil layer were extracted using the core technique (Drew and Saker 1980). A stainless steel pipe with $37.5 \mathrm{~mm}$ inside diameter was driven into the soil with a motorized hammer at a $10-\mathrm{cm}$ depth increment. The soil mass was soaked in $5 \%$ sodium hexametaphosphate solution overnight and washed over a sieve size $0.5 \mathrm{~mm}$ diameter to retrieve the roots. Root length was determined by the line intersect method (Newman 1966) as modified by Rowse and Phillips (1974). Five cores were extracted at randomly selected positions within the plot.

\subsubsection{Analysis of data}

All data were evaluated using classical statistical methods for calculating mean, maximum, standard deviation and coefficient of variation using STATISTICA v. 5.0. Differences in the studied properties between study plots were tested by one-way analysis of variance (ANOVA) using the PROC GLM command of the SAS statistical package (SAS Institute Inc. 1991). Since the data of some properties did not show normal distribution, they were log-transformed to improve the normality of distribution (Snedecor and Cochran 1980). The Tukey's test $(p<0.05)$ was used to evaluate significant differences between means of plots and soil layers.

\section{Results}

\subsection{Soil physical properties}

The ANOVA showed significant influence $(p<0.05)$ of plot and depth on all the parameters measured and their interactions. The bulk densities of subsoil layers in all the profiles were very high (range 1.96-2.04; mean 
Table 2 Bulk density, water sorptivity and water stable aggregates in profiles of plots used for urban and peri-urban agriculture in the city of Mahikeng

\begin{tabular}{|c|c|c|c|c|c|}
\hline Soil layer & Unit 5 & Unit 6 & Golf view & Reviera Park & Mean $\pm \mathrm{SD}$ \\
\hline \multicolumn{6}{|c|}{ Bulk density $\left(\mathrm{Mg} \mathrm{m}^{-3}\right) ; n=5$} \\
\hline Top & $1.26 \pm 0.03 \mathrm{a}$ & $1.18 \pm 0.05 b$ & $1.36 \pm 0.04 \mathrm{a}$ & $1.26 \pm 0.13 \mathrm{a}$ & $(1.27 \pm 0.07)$ \\
\hline Sub & $1.96 \pm 0.48 \mathrm{a}$ & $2.02 \pm 0.21 b$ & $2.04 \pm 0.32 b$ & $1.98 \pm 0.17 \mathrm{a}$ & $(2.06 \pm 0.04)$ \\
\hline \multicolumn{6}{|c|}{ Water sorptivity $\left(\mathrm{mm} \mathrm{h}^{-1}\right) ; n=4$} \\
\hline Top & $24.3 \pm 2.3 \mathrm{a}$ & $20.6 \pm 2.5 b$ & $27.4 \pm 3.6 \mathrm{c}$ & $21.4 \pm 1.3 b$ & $(23.4 \pm 3.1)$ \\
\hline Sub & $09.7 \pm 0.4 \mathrm{a}$ & $07.8 \pm .1 .2 \mathrm{~b}$ & $10.4 \pm .1 .1 \mathrm{c}$ & $6.7 \pm .0 .2 \mathrm{~b}$ & $(8.7 \pm 1.7)$ \\
\hline \multicolumn{6}{|c|}{ Aggregate stability $(\%>2 \mathrm{~mm}) ; n=10$} \\
\hline Top & $73.5 \pm 5.0 \mathrm{a}$ & $76.3 \pm 2.4 \mathrm{~b}$ & $71.6 \pm 1.3 \mathrm{c}$ & $75.7 \pm 1.8 \mathrm{~b}$ & $(74.3 \pm 2.2)$ \\
\hline Sub & $27.1 \pm 4.6 \mathrm{a}$ & $30.2 \pm 3.1 \mathrm{~b}$ & $25.3 \pm 2.2 \mathrm{a}$ & $21.8 \pm 3.5 \mathrm{c}$ & $(26.1 \pm 3.5)$ \\
\hline
\end{tabular}

Values are mean $\pm \mathrm{SD}$; means within a row with similar letters are not significantly different $(p=0.05)$ by the LSD test; values in brackets represent means $\pm \mathrm{SD}$ within the horizon
$2.01 \mathrm{Mg} \mathrm{m}^{-3}$ ) while the values for the top layers were low (range 1.18-1.36; mean $1.27 \mathrm{Mg} \mathrm{m}^{-3}$ ) (Table 2). In all the profiles, there was a sharp distinction in the mean bulk density values between the topsoil $\left(1.27 \mathrm{Mg} \mathrm{m}^{-3}\right)$ and subsoil (2.06 $\mathrm{Mg} \mathrm{m}^{-3}$ ) layers. This observation was consistent with the exceedingly high compaction levels in all the subsoil layers (maximum mean penetrometer resistance $1.89 \mathrm{MPa}$ ) shown in Fig. 2. The high penetrometer resistance and bulk density of soils in this layer imply problems of root penetration (Fig. 3) and suggest that impeded drainage could be encountered through this layer.

The trend in values of the hydraulic properties of the subsoil layers (Table 2) mirrored those of bulk density in that the sorptivity of water in all the profiles was in the topsoil moderate (mean $23.4 \mathrm{~mm} \mathrm{~h}^{-1}$ ) and the subsoil low (mean
$8.7 \mathrm{~mm} \mathrm{~h}^{-1}$ ). The mean stability to water, of aggregates in the subsoil layers $(26.1 \%)$ of all the profiles, was generally low especially when compared with the surface soil (74.3\%). The weak structure could be explained by the light texture and low organic matter of the soil in these layers.

\subsection{Soil chemical and biological properties}

The $\mathrm{pH}$ of the subsoil layers was moderately acidic (range 6.12-6.34) and showed slightly lower mean $\mathrm{pH}$ values (6.22) than their topsoil (6.40) counterparts (Table 3). It was not surprising to observe very low levels (mean $0.53 \mathrm{ppm}$ ) of available phosphorus in this layer compared to $9.35 \mathrm{ppm}$ in the top soil. This reflects the strong phosphorus fixing characteristic of iron oxides which characterize the structured B

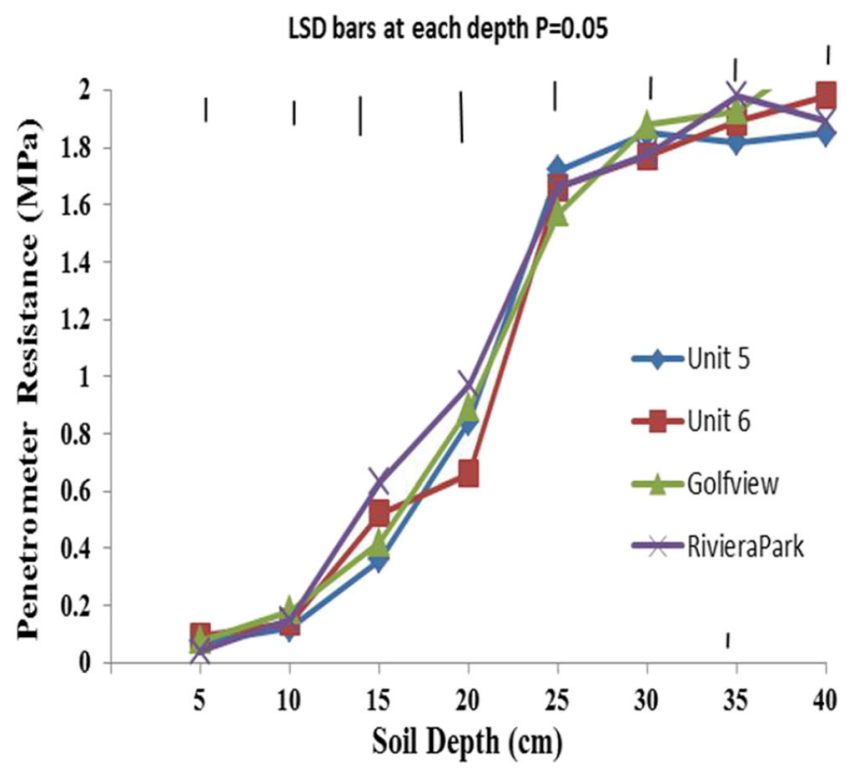

Fig. 2 Soil penetrometer resistance in the profiles of plots used for urban agriculture in the city of Mafikeng. Bars represent LSD $(p=0.05)$ at each soil depth

\section{LSD bars at each depth $P=0.05$}

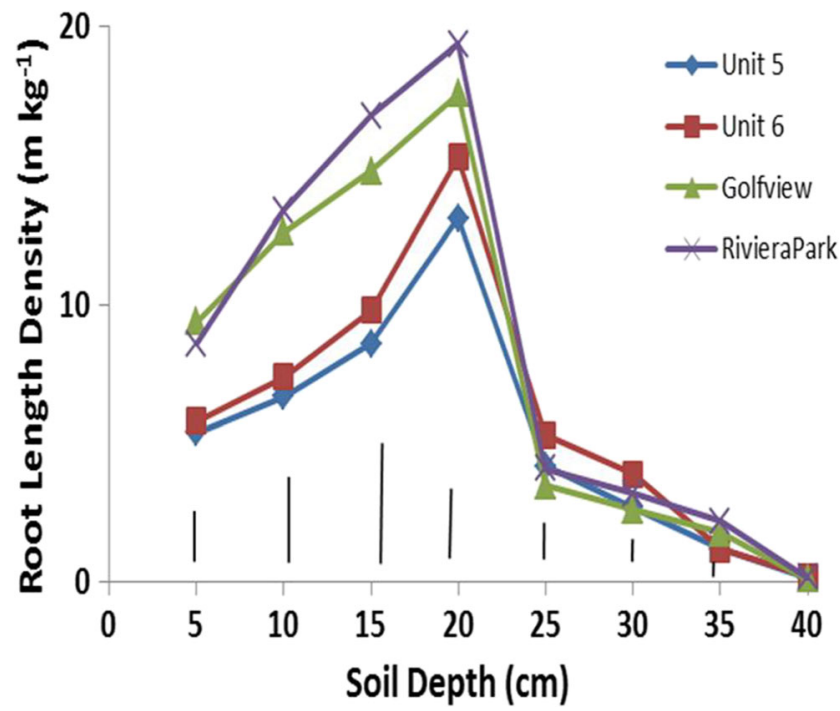

Fig. 3 Root length density in the profiles of plots used for urban agriculture in the city of Mafikeng. Bars represent LSD $(p=0.05)$ at each soil depth 
Table 3 Soil $\mathrm{pH}$, available phosphorus and boron in profiles of plots used for urban and periurban agriculture in the city of Mahikeng

\begin{tabular}{|c|c|c|c|c|c|}
\hline Soil layer & Unit 5 & Unit 6 & Golf view & Reviera Park & Mean $\pm \mathrm{SD}$ \\
\hline \multicolumn{6}{|c|}{$\mathrm{pH}$ (water); $n=5$} \\
\hline Top & $6.33 \pm 0.17 \mathrm{a}$ & $6.41 \pm 0.03 \mathrm{a}$ & $6.52 \pm 0.10 \mathrm{~b}$ & $6.33 \pm 0.08 \mathrm{a}$ & $(6.40 \pm 0.09)$ \\
\hline Sub & $6.12 \pm 0.11 \mathrm{a}$ & $6.23 \pm 0.25 b$ & $6.34 \pm 0.28 \mathrm{a}$ & $6.17 \pm 0.06 \mathrm{a}$ & $(6.22 \pm 0.07)$ \\
\hline \multicolumn{6}{|c|}{ Available $\mathrm{P}(\mathrm{ppm}) ; n=10$} \\
\hline Top & $8.3 \pm 0.67 \mathrm{a}$ & $9.2 \pm 0.92 \mathrm{~b}$ & $11.8 \pm 0.10 \mathrm{c}$ & $9.1 \pm 0.13 \mathrm{~d}$ & $(9.35 \pm 1.9)$ \\
\hline Sub & $0.3 \pm 0.11 \mathrm{a}$ & $0.4 \pm 0.38 \mathrm{a}$ & $0.9 \pm 0.07 \mathrm{~b}$ & $0.5 \pm 0.16 \mathrm{a}$ & $(0.53 \pm 0.26)$ \\
\hline \multicolumn{6}{|c|}{ Boron $\left(\mathrm{mg} \mathrm{kg}^{-1}\right) ; n=5$} \\
\hline Top & $0.11 \pm 0.03 a$ & $0.09 \pm 0.02 b$ & $0.05 \pm 0.01 \mathrm{c}$ & $0.17 \pm 0.04 a$ & $(0.11 \pm 0.05)$ \\
\hline Sub & $0.57 \pm 0.02 \mathrm{a}$ & $0.37 \pm 0.01 b$ & $0.48 \pm 0.05 \mathrm{c}$ & $0.36 \pm 0.02 \mathrm{c}$ & $(0.45 \pm 0.10)$ \\
\hline
\end{tabular}

Values are mean $\pm \mathrm{SD}$; means within a row with similar letters are not significantly different $(p=0.05)$ by the LSD test; values in brackets represent means $\pm \mathrm{SD}$ within the horizon horizon of these ferralitic profiles. The boron levels in all the soils were generally low (range $0.36-0.57$ ) and non-toxic to plants according to the FSSA (2003) as they were all below $5 \mathrm{mg} \mathrm{kg}^{-1}$. The mean boron content was higher in subsoil $\left(0.45 \mathrm{mg} \mathrm{kg}^{-1}\right)$ compared to topsoil layers $(0.11 \mathrm{mg} \mathrm{kg}-1)$. The elevated levels of boron in subsoil layers may suggest that the borate which is in the compound fertilizer used by some of the farmers was leached from the surface layers during irrigation.

Table 4 shows mixed trends in the exchangeable cations in the subsoil layers. Calcium, potassium and sodium showed an increase in concentration while magnesium displayed the reverse. Generally, the levels of all the cations were low and not restrictive to plant development according to the FSSA (2003). The concentration of exchangeable calcium, magnesium, potassium and sodium were significantly higher $(p<0.05)$ in the subsoil compared with topsoil layers. There were large variations between the sites with unit 6 displaying relatively higher values than the other sites. Similar trends were observed for $\mathrm{Mg}$ and $\mathrm{K}$. The concentration of sodium was much less in magnitude than those of calcium, magnesium and potassium.

The organic carbon and microbial biomass carbon of the subsoil layers of all the plots were very low (Table 5). The generally low organic carbon content (mean $0.78 \%$ ) of the subsoil layers across all the profiles is of concern as it may contribute adversely to the quality of the soil. As expected, the low carbon levels were reflected by a low protease enzyme activity due to lack of the necessary substrate required for microbial survival and activity. Furthermore, the lack of substrate for microbial survival was confirmed by the lack of root proliferation in the subsoil layers (Fig. 3). There was a steep reduction in the root length density in all the subsoil layers compared to surface layers. Visual observations made during soil sampling revealed very limited mesofauna and macrofauna (earthworms, termites, ants) activity in all the subsoil layers. It was not surprising therefore to observe very limited enzyme activity in these layers as soil microorganisms and plant roots are the main catalysts for soil enzymes.
Table 4 Exchangeable cations in profiles of plots used for urban and peri-urban agriculture in the city of Mahikeng

\begin{tabular}{|c|c|c|c|c|c|}
\hline Soil layer & Unit 5 & Unit 6 & Golf view & Reviera Park & Mean \pm SD \\
\hline \multicolumn{6}{|c|}{ Exchangeable $\mathrm{Ca}\left(\mathrm{cmol}_{\mathrm{c}} \mathrm{kg} \mathrm{soil}{ }^{-1}\right)$} \\
\hline Top & $30.4 \pm 5.3 \mathrm{a}$ & $28.6 \pm 3.3 b$ & $35.2 \pm 1.7 \mathrm{c}$ & $31.7 \pm 2.6 \mathrm{a}$ & $(31.5 \pm 2.8)$ \\
\hline Sub & $56.2 \pm 1.8 \mathrm{a}$ & $74.2 \pm 6.1 \mathrm{~b}$ & $65.3 \pm 5.4 \mathrm{c}$ & $68.4 \pm 6.5 \mathrm{c}$ & $(66.1 \pm 7.5)$ \\
\hline \multicolumn{6}{|c|}{ Exchangeable $\mathrm{Mg}\left(\mathrm{cmol}_{\mathrm{c}} \mathrm{kg}\right.$ soil $\left.^{-1}\right)$} \\
\hline Top & $21.2 \pm 0.7 \mathrm{a}$ & $36.5 \pm 4.1 \mathrm{~b}$ & $28.4 \pm 4.2 \mathrm{c}$ & $33.6 \pm 3.6 b$ & $(29.9 \pm 6.7)$ \\
\hline Sub & $13.6 \pm 3.8 \mathrm{a}$ & $15.7 \pm 3.6 \mathrm{~b}$ & $11.4 \pm 1.1 \mathrm{c}$ & $14.2 \pm 1.3 \mathrm{~d}$ & $(13.7 \pm 1.8)$ \\
\hline \multicolumn{6}{|c|}{ Exchangeable $\mathrm{K}\left(\mathrm{cmol}_{\mathrm{c}} \mathrm{kg}\right.$ soil $\left.^{-1}\right)$} \\
\hline Top & $3.1 \pm 0.4 \mathrm{a}$ & $4.4 \pm 0.8 b$ & $2.3 \pm 0.7 \mathrm{c}$ & $3.5 \pm 0.4 \mathrm{a}$ & $(3.3 \pm 0.9)$ \\
\hline Sub & $9.8 \pm 1.3 \mathrm{a}$ & $10.2 \pm 1.6 \mathrm{a}$ & $8.3 \pm 1.5 b$ & $11.1 \pm 2.7 \mathrm{c}$ & $(9.9 \pm 1.2)$ \\
\hline \multicolumn{6}{|c|}{ Exchangeable $\mathrm{Na}\left(\mathrm{cmol}_{\mathrm{c}} \mathrm{kg} \mathrm{soil}^{-1}\right)$} \\
\hline Top & $0.8 \pm 0.3 \mathrm{a}$ & $0.4 \pm 0.8 b$ & $0.3 \pm 0.1 \mathrm{~b}$ & $0.7 \pm 0.5 \mathrm{a}$ & $(0.6 \pm 0.2)$ \\
\hline Sub & $2.2 \pm 1.3 \mathrm{a}$ & $3.2 \pm 1.1 \mathrm{~b}$ & $2.3 \pm 0.5 \mathrm{a}$ & $2.0 \pm 0.7 \mathrm{a}$ & $(2.4 \pm 0.5)$ \\
\hline
\end{tabular}

Values are mean \pm SE; means within a row with similar letters are not significantly different $(p=0.05)$ by the LSD test; values in brackets represent means $\pm \mathrm{SD}$ within the horizon 
Table 5 Soil biological properties in profiles of plots used for urban and peri-urban agriculture in the city of Mahikeng

\begin{tabular}{|c|c|c|c|c|c|}
\hline Soil layer & Unit 5 & Unit 6 & Golf view & Reviera Park & Mean $\pm \mathrm{SD}$ \\
\hline \multicolumn{6}{|c|}{ Organic carbon $(\%) ; n=6$} \\
\hline Top & $1.15 \pm .11 \mathrm{a}$ & $1.47 \pm .22 b$ & $1.22 \pm .08 \mathrm{a}$ & $1.14 \pm .16 \mathrm{a}$ & $(1.25 \pm 0.15)$ \\
\hline Sub & $0.85 \pm .06 \mathrm{a}$ & $0.67 \pm .02 b$ & $0.82 \pm .16 \mathrm{a}$ & $0.73 \pm .10 \mathrm{c}$ & $(0.78 \pm 0.08)$ \\
\hline \multicolumn{6}{|c|}{ Microbial biomass $\mathrm{C}\left(\mathrm{mg} \mathrm{C} \mathrm{kg}^{-1}\right) ; n=5$} \\
\hline Top & $156 \pm 14 \mathrm{a}$ & $118 \pm 07 b$ & $123 \pm 09 b$ & $107 \pm 06 c$ & $(126 \pm 21)$ \\
\hline Sub & $38 \pm 08 \mathrm{a}$ & $49 \pm 05 b$ & $21 \pm 06 \mathrm{c}$ & $39 \pm 08 \mathrm{a}$ & $(36.8 \pm 12)$ \\
\hline \multicolumn{6}{|c|}{ Protease enzyme activity $\left(\mu \mathrm{mol} \mathrm{g}{ }^{-1} \mathrm{~h}^{-1}\right) ; n=10$} \\
\hline Top & $0.42 \pm .03 \mathrm{a}$ & $0.51 \pm .03 b$ & $0.74 \pm .05 \mathrm{a}$ & $0.38 \pm .06 \mathrm{c}$ & $(0.51 \pm 0.16)$ \\
\hline Sub & $0.08 \pm .01 \mathrm{a}$ & $0.07 \pm .05 \mathrm{a}$ & $0.11 \pm .02 \mathrm{a}$ & $0.10 \pm .01 \mathrm{a}$ & $(0.09 \pm 0.12)$ \\
\hline
\end{tabular}

Values are mean $\pm \mathrm{SD}$; means within a row with similar letters are not significantly different $(p=0.05)$ by the LSD test; values in brackets represent means $\pm \mathrm{SD}$ within the horizon

\section{Discussion}

Irrigation was considered by all the farmers to be critical for crop production because, although the soils (ferralsols) have good physical properties such as soil depth $(>1.0 \mathrm{~m})$, it displayed signs of good drainage in the topsoil, friable and easy to work. However, they have a tendency to store insufficient water at depth to sustain crops through dry spells which occur frequently during the growing season (Fey 2010). This makes dry land production more risky as Mahikeng is dry with very low annual rainfall which is erratic and highly variable. It was however observed that overirrigation was common among the farmers due to poor irrigation scheduling and surface ponding was evident.

Although soil compaction is only one aspect of the much wider problems of physical, chemical and biological soil degradation, its presence induces changes in soil behaviour characteristics that are critical as they in turn influence the other properties. Håkansson et al. (1988), for example, have shown that subsoil compaction is the principal constraint on root growth and activity due to low aeration, high soil strength and low rates of water movement that restrict water and nutrient supply to the crop. As has been observed elsewhere in South Africa (Bennie and Burger 1988; Van Antwerpen et al. 2008), compaction and low moisture holding capacity are major problems associated with tillage on light-textured soils with low clay content.

This study has exposed the existence of subsoil constraints in all the profiles of urban agriculture plots studied. Based on the proposed threshold values given for field crops by the FSSA (2003), the physical and biological constraints were more prominent than chemical constraints. The very high compaction levels that existed in the subsoil layers are attributed to weak soil aggregates that disintegrated easily when moist and formed a dense layer just below the plough layer. The susceptibility of Hutton form soils to structural degradation under different management systems in South Africa has been well documented (Smith et al. 1997; Van Antwerpen et al. 2008) and shows that the structure of the soil collapses when exposed to water and uni-axial pressure is applied (Van Antwerpen and Meyer 1996). This suggests that soil structure is probably the key soil characteristic that is affecting the physical and biological properties of the subsoil layers in this study.

Soil compaction in South African soils originates from tillage and traffic of wheeled vehicles associated with continuous cultivation and intensive cropping ( $\mathrm{Nel}$ and Bennie 1984; Mallett et al. 1985; Tanner et al. 1986; Scotney and Dijkhuis 1990). The use of draft animals for mouldboard ploughing and other field operations in many areas is widely recognized as an important source of compaction (Bennie and Krynauw 1985; Bennie 1996; Smith et al. 1997). The hoofs of grazing and draft animals exert high but somewhat variable ground contact pressures, depending on the mass of the animals and area of the hoof (Kuipers and van de Zande 1994). According to Kuipers and van de Zande (1994), typical values for a 530$\mathrm{kg}$ ox are $130 \mathrm{kPa}$ standing and $250 \mathrm{kPa}$ walking. Many soils also display hardsetting properties which can extend into the subsoil (Lambrechts and MacVicar 2004).

Le Roux and Du Prezz (2006) and Lambrechts and MacVicar (2004) have shown that the profiles of soils under both urban and agricultural fields have a higher subsoil compaction than that of uncultivated soils. The compaction however seems to be more intense in rural agricultural than in urban agricultural fields. This could be because tillage and traffic is more intense and regular in cultivated soils compared to urban agriculture fields. The size of tractor and machinery used under urban agriculture are generally smaller with lighter axle loads than those in arable fields. Similarly, more livestock grazing takes place in rural cultivated fields than in urban agricultural plots due to by-laws that restrict animals in the city.

The excessively high compaction levels at the base of the plough layers does not only prevent root penetration but also lead to the formation of a perched water table, especially when excessive irrigation is applied as was observed in most of the 
study plots. Such a perched water table could, if it lasts long, give rise to anaerobic conditions which can affect the growth and activities of both roots and microorganisms, including fluxes of $\mathrm{N}_{2} \mathrm{O}$ and other nutrients (Otter and Scholes 2000). Thus, although the data in this study could not be used to directly project the effects of the constraints on plant productivity, it is however argued that the constraints have the potential to influence not only root growth but also productivity of crops as has been well established by many studies elsewhere (Bennie and Krynauw 1985; Van Huyssteen 1988; Scott et al. 1997; Nuttall et al. 2004; Dang et al. 2006; Kirkegaard et al. 2006, 2007; Adcock et al. 2007; Lisson et al. 2007; Swan et al. 2011; McDonald et al. 2012). Anecdotal evidence exists, and most urban agriculture farmers recognize that soil degradation due to subsoil compaction is visually evident among urban agriculture fields in the form of reduced crop establishment, growth, yield and quality of crops grown. However, accurate yield data were not readily available among the farmers to allow a more valid comparison of crop yields in soils with subsoil compaction with those without it under similar management conditions.

It is suggested that farmers who are practising urban agriculture should take cognizance of the problem of subsoil compaction and begin to adopt potential management options and ameliorative actions. According to Horn (2000), the key to alleviating subsoil constraints is to improve the soil structure which will in turn facilitate increased root growth into the subsoil. Occasional deep ploughing (ripping) through the dense layer has been shown to improve the growth of roots into compact subsoil layers (Mead and Chan 1988). Furthermore, Gill et al. (2009) have shown that the effects of deep ripping are reflected more by injecting large volumes of nutrient-rich organic amendments into the profile with the deep ripping (subsoil manuring). This has been shown to initiate the formation and stabilization of soil aggregates and improve the physical fertility and increase crop yields (Clark et al. 2007). As a result, crops extracted more water from the subsoil and the increased water uptake was a major factor contributing to increased yield (Clark et al. 2007; Gill et al. 2012). The amendments are also said to reduce bulk density, increase macroporosity and increase root length density at the depth of amendment (Gill et al. 2009). The improved yield with amendments was related to an increase in plant available water in the hostile subsoil and prolonged greenness of leaves and supply of nitrogen and other nutrients (McDonald et al. 2012).

Other possible management options include the use of raised beds to improve soil structure through increasing air porosity and drainage in soils where waterlogging occurs frequently (Kooistra and Boersma 1994). Choice of different crop type and cultivar offers another best strategy to overcome subsoil constraints as rooting patterns of crop species vary and may help in modifying the subsoil environment (Yunusa and
Newton 2003; Nuttall et al. 2010). Biopores created by taprooted plants, also termed primer-crops, such as lucerne, lupin and canola, have been shown to be more effective than mechanical tillage in opening up channels in some subsoil for the roots of subsequent crops (Elkins 1985; Cresswell and Kirkegaard 1995; Lynch and Wojciechowski 2015). The roots of these crops also grow deeper and use water more efficiently than shallow-rooted annual crops (Cresswell and Kirkegaard 1995).

Since the suggested strategies, and any others, that involve the amelioration of the subsoil are expensive and time-consuming, it is recommended that an economic analysis is undertaken before embarking on any strategy such as deep ripping (Arvidson et al. 2000; Petersen 2011). In general, sound agronomic management should always be considered in order to minimize the water and other physiological stresses imposed by subsoil constraints (Noble and Lea 1984; Thompson 1986; Walt 1991).

\section{Conclusions}

The study has highlighted that subsoil layers in plots used for urban agriculture within the city of Mahikeng possess constraints associated with unfavourable physical and biological properties. Most of the profiles had physical impediment to root growth in the subsoil that would limit the ability of plants to utilize soil water and nutrient resources which is detrimental to plant growth. Since these properties are associated with root growth, water and oxygen movement and biological activities, it is likely that yields of some crops will be reduced due to the conditions created by the constraints. It is recommended that urban agriculture farmers should begin to consider adopting management practices that can alleviate subsoil constraints including occasional deep ripping, addition of organic matter in the subsoil and use of plant species with the ability to penetrate and open up the compact subsoil layers. The pores created by roots of such plants could help to improve subsoil water use by crops.

Acknowledgments The study was funded by the National Research Foundation (NRF) under the Incentive Grant for Rated Researchers (Number 80999). I thank the owners of plots that were used for allowing access. Comments made by the two anonymous reviewers on the original manuscript are greatly acknowledged.

Open access This article is distributed under the terms of the Creative Commons Attribution License which permits any use, distribution and reproduction in any medium, provided original author and the source are credited. 


\section{References}

Acosta-Martinez V, Klose S, Zobeck TM (2003) Enzyme activities in semiarid soils under conservation reserve program, native rangeland, and cropland. J Plant Nutr Soil Sci 166:699-707

Adcock D, McNeill AM, McDonald GK, Armstrong RD (2007) Subsoil constraints to crop production on neutral and alkaline soils in southeastern Australia: a review of current knowledge and management strategies. Aust J Expt Agric 47:1245-1261

Altieri MA (2002) Agro ecology: the science of natural resource management for poor farmers in marginal environments. Agric Ecosyst Environ 93:1-24

ARC-ISCW (2004) Overview of the status of the agricultural natural resources of South Africa. ARC-ISCW Report no GW/A/2004/13. Agricultural Research Council-Institute for Soil Climate and Water, Pretoria, South Africa

Arvidson J, Trautner A, Van den Akker JH (2000) Subsoil compactionrisk assessment and economic consequences. In: Horn R, van den Akker JJ, Arvidson J (eds) Subsoil Compaction: Distribution, Processes and Consequences, Advances in Geoecology, CATENA VERLAG GMBH, Reiskirchen, p 3-12

Beater BA (1962) The sampling and analyses of field soils. South African Sugar Association, Experimental Station, Mount EdgeCombe, Natal, South Africa

Bennie ATP (1996) Growth and mechanical impedence. Chapter 23. In: Waisel Y, Eshel A, Kafkafi U (eds) Plant roots: the hidden half, Second Revised edn. Marcel Dekker Inc., New York

Bennie ATP, Krynauw GN (1985) Causes, adverse effects and control of soil compaction. Sth Afr J Plant Soil 2:109-114

Bennie ATP, Burger R, du T (1988) Penetration resistance of fine sandy apedal soils as affected by relative bulk density, water content and texture. S Afr J Plant Soil 5(1):5-10

Blake GR, Hartge KH (1986) Bulk density. In: Klute A (ed) Methods of soil analysis. Part I, physical and mineralogical methods, Agronomy Monograph No. 9, 2nd edn. American Society of Agronomy, Madison, pp. 363-375

Bray RH, Kurtz LT (1945) Determination of total organic and available forms of phosphorus in soils. Soil Sci 59:39-45

Brookes PC, Landman A, Pruden G, Jenkinson DS (1985) Chloroform fumigation and the release of nitrogen: a rapid direct extraction method to measure microbial biomass nitrogen in soil. Soil Biol Biochem 17:837-824

Clark GJ, Dodgshun N, Sale PWG, Tang C (2007) Changes in chemical and biological properties of a sodic clay subsoil with addition of organic amendments. Soil Biol Biochem 39:2806-2817

Cresswell HP, Kirkegaard JA (1995) Subsoil amelioration by plant roots - the process and the evidence. Aust J Soil Res 33:221-239

DAFF (Department of Agriculture, Forestry and Fisheries) (2011) South African agricultural production strategy. 2011-2025. DAFF, Pretoria, South Africa

Dang YP, Dalal RC, Routley R, Schwenke GD, Daniells I (2006) Subsoil constraints to grain production in the cropping soils of the northeastern region of Australia: an overview. Aust J Exptl Agric 46:19-35

Dang YP, Dalal RC, Buck SR, Harms B, Kelly R, Hochman Z, Schwenke GD, Biggs AJW, Ferguson NJ, Norrish S, Routley R, McDonald M, Hall C, Singh DK, Daniells IG, Farquharson R, Manning W, Speirs S, Grewal HS, Cornish P, Bodapati N, Orange D (2010) Diagnosis, extent, impacts and management of subsoil constraints in the northern grains cropping region of Australia. Aust J Soil Res 48:105-119

Danie J, Beukes A, Bennie TP, Hensley M (2004) Optimizing soil water balance components for sustainable crop production in dry areas of South Africa. Challenges and strategies of dryland agriculture, vol 32. Crop Science Society, America Special Publication, pp. 291313. doi:10.2135/cssaspecpub32.c19
Day PR (1965) Particle fractionation and particle-size analysis. In: Black CA , Evans DD, White JL, Ensminger LE, Clark FE (eds) Methods of soil analysis. Part 1. Physical and mineralogical methods, 1 st edn. American Society of Agronomy Monograph No. 9, Madison, WI, pp. $545-567$

Drew MC, Saker LR (1980) An assessment of a rapid method using soil cores for estimating the amount and distribution of crop roots in the field. Plant Soil 55:297-305

Elkins CB (1985) Plant roots as tillage tools. In: Proc. Int. Conf. Soil Dynamics Vol. 3: Tillage Machinery Systems as Related to Cropping Systems. Auburn, Alabama, pp 519-523

FAO-ISS-ISRIC (1998) World reference base for soil resources. World Soil Resource Report 84. FAO, Rome, Italy

Farina MPW, Channon P (1988) Acid-subsoil amelioration. I. A comparison of several mechanical procedures. Soil Sci Soc Am J 34:893-896

Farina MPW, Channon P, Thibaud GR (1998) A comparison of strategies for ameliorating subsoil acidity II. Long-term soil effects. Soil Sci Soc Am J 64:652-658

Fey M (2010) Soils of South Africa: their distribution, properties, classification, genesis, use and environmental significance. Cambridge University Press, Cape Town, South Africa

FSSA (Fertilizer Society of South Africa) (2003) Fertilizer Society of South Africa Fertilizer Handbook, 5th edn. Fertilizer Society of South Africa, Lynnwood Ridge, Pretoria

Gill JS, Sale PWG, Peries RR, Tang C (2009) Changes in soil physical properties and crop root growth in dense sodic subsoil following incorporation of organic amendments. Field Crops Res 114:137-146

Gill JS, Sale P, Clark GK, Peries RR, Tang C (2012) Deep placement of organic amendments in dense sodic subsoil increases summer fallow efficiency and the use of deep soil water by crops. Plant Soil 359:57-69

Gliessman SR (1990) Agroeology: researching the ecological basis for sustainable agriculture. Agro Ecol 78:3-10

Graham RD, Turner NC, Ascher JS (1992) Evidence of subsoil constraints and potential benefits from amelioration. In Proceedings of the national workshop on subsoil constraints to root growth and high soil water and nutrient use by plants. CSIRO Soils, Adelaide, South Australia

Håkansson I, Voorhees WB, Riley H (1988) Weather and other environmental factors influencing crop responses to tillage and traffic. Soil Till Res 11:239-282

Haynes RJ, Graham MH (2004) Soil biology and biochemistry - a new direction for South African soil science? S Afr J Plant Soil 21(5): 330-344

Horn R (2000) Introductory remarks. In: Horn R, van den Akker JJ, Arvidson, J (eds) Subsoil compaction: distribution, processes and consequences. Advances in Geoecology, CATENA VERLAG GMBH, Reiskirchen, p 462

IUSS Working Group WRB (2015) World Reference Base for Soil Resources 2014. Update 2015. International soil classification system for naming soils and creating legends for soil maps. World Soil Resources Report No. 106, FAO, Rome

Jackson ML (1964) Soil chemical analysis, 4th edn. Prentice-Hall, Englewood Cliffs, NJ

Jayawardane NS, Chan KY (1994) The management of soil physical properties limiting crop production in Australian sodic soil-a review. Aust J Soil Res 32:13-44

Kirkegaard JA, Robertson MJ, Hamblin P, Sprague ST (2006) Effect of blackleg and sclerotinia stem rot on canola yield in the high rainfall zone of southern New South Wales, Australia. Aust J Agric Res 57: 201-211

Kirkegaard JA, Lilley JM, Howe GN, Graham JM (2007) Impact of sub soil water use on wheat yield. Aust J Agric Res 58:303-315

Kooistra MJ, Boersma OH (1994) Subsoil compaction in Dutch marine sandy loams-loosening practices and effects. Soil Till Res 29:237-247

Kuipers H, van de Zande JC (1994) Quantification of traffic systems in crop production. Chapter 18. In: Soane BD, van Ouwerkerk C (eds) 
Soil compaction in crop production. Elsevier Science B.V, Amsterdam, The Netherlands, pp. 417-446

Lambrechts JJN, MacVicar CN (2004) Soil genesis and classification and soil resources databases. S Afr J Plant Soil 21:288-300

Le Roux PAL, Du Prezz CC (2006) Nature and distribution of South African plinthic soils: conditions for occurrence of soft and hard plinthic soils. S Afr J Plant Soil 23:120-125

Lisson SN, Kirkegaard JA, Robertson MJ, Zwart A (2007) What is limiting canola yield in southern New South Wales? A diagnosis of causal factors. Aust J Expt Agric 47:1435-1445

Lynch JP, Wojciechowski T (2015) Opportunities and challenges in the subsoil: pathways to deeper rooted crops. J. Expt Bot 66:2199-2210

MacEwan RJ, Crawford DM, Newton PJ, Clune TS (2010) High clay contents, dense soils, and spatial variability are the principal subsoil constraints to cropping the higher rainfall land in south-eastern Australia. Aust J Soil Res 48:150-166

Mahikeng Local Municipality (2013) Mahikeng Local Municipality Audited Annual Report 2012/2013. City Council of Mahikeng, Mmabatho

Mail \& Guardian (2016) 7th Africities Summit: Africa "does urbanisation" its own way. An Advertising Supplement to the Mail \& Guardian. A MGAfrica.com production December 232015 to January 2016

Mallett JB, Koch CD, Visser PA, Botha AJ (1985) Tillage-related soil compaction and its effect upon maize grain yields on a Viljoenskroon fine sand. S Afr J Plant Soil 2:52-56

Materechera SA (2009) Tillage and tractor traffic effects on soil compaction in horticultural fields used for peri-urban agriculture in a semiarid environment of the North West Province, South Africa. Soil Till Res 103:11-15

Materechera SA (2011) Soil salinity in irrigated fields used for urban agriculture under a semi-arid environment of South Africa. African J Agric Res 6:3747-3754

Materechera SA (2014) Influence of agricultural land use and management practices on selected soil properties of a semi-arid savannah environment in South Africa. J Arid Environ 102:98-103

Materechera SA, Gaobope K (2007) Soil compaction by tractor tillage in horticultural fields at Molelwane research farm, Mahikeng, North West province. S Afr J Plant Soil 24:58-61

Matson PA, Parton WJ, Power AG, Swift MJ (2007) Agricultural intensification and ecosystem properties. Science 277:504-509

McDonald G, Taylor J, Verbyla A, Kuchel H (2012) Assessing the importance of subsoil constraints to yield of wheat and its implications for yield improvement. Crop Pasture Sci 63:1043-1065

Mead JA, Chan KY (1988) Effect of deep tillage and seedbed preparation on the growth and yield of wheat on a hard-setting soil. Aust J Expt Agric 28:491-498

Mead A, Hertel K, Cole C, Nicol H (2005) Constraints to canola in central and southern NSW. 14th Australian Research Assembly on Brassicas, Port Lincoln, South Australia

Mullins CE, Macleod DA, Northcote KH, Tisdall JM, Young IM (1990) Hard-setting soils: behaviour, occurrence and management. Adv Soil Sci 11:37-108

Nel DJ, Bennie ATP (1984) Soil factors affecting tree growth and root development in a citrus orchard. S Afr J Plant Soil 1:39-47

Newman EI (1966) A method for estimating the total length of roots in a sample. J Appl Ecol 3:139-145

Noble AD, Lea JD (1984) Response of five soybean (Glycine max (L.) merr.) cultivars to lime and phosphorus on an acid Normandien subsoil. S Afr J Plant Soil 1:51-56

Nuttall JG, Armstrong RD (2010) Impact of subsoil physicochemical constraints on crops grown in the Wimmera and Mallee is reduced during dry seasonal conditions. Aust J Soil Res 48:125-139

Nuttall J, Armstrong R, Imhof M, Abuzar M, Belford R (2004) Subsoil constraints to dryland crop production on the low rainfall alkaline soils of Southeastern Australia. Crop Sci Soc Am Special
Publication, Challenges and Strategies of Dryland Agriculture 32: 373-387

Nuttall JG, Hobson KB, Materne M, Moody DB, Munns R, Armstrong $\mathrm{RD}$ (2010) Use of genetic tolerance in grain crops to overcome subsoil constraints in alkaline cropping soils. Aust J Soil Res 48: 188-189

O'Leary G, Roget D, Sadras V (2004) Identify subsoil problems to increase profits. Farming Ahead No. 152 September 2004. CSIRO Land and Water, pp 54-56

Okalebo JR, Gathua KW, Woomer PL (1993) Laboratory methods of soil and plant analysis: a working manual. TSBF-KARI, Marvel EPZ Ltd., Nairobi, Kenya

Otter LB, Scholes MC (2000) Methane sources and sinks in periodically flooded South African savanna. Glob Biogeochem Cycles 14:97-111

Perroux KM, White KM (1988) Designs for disc permeameters. Soil Sci Soc Am J 52:1205-1215

Petersen E (2011) Economic analysis of the impacts and management of subsoil constraints report. Department of Agriculture and Food, Western Australia's (DAFWA) economist, for the Grains Research and Development Corporation funded project: "DAW00242: Subsoil constraints-understanding and management". 17th Australian Research Assembly on Brassicas (ARAB) Wagga Wagga Australia. p 128

Rowse HR, Phillips DA (1974) An instrument for estimating the total length of root in a sample. J Appl Ecol 11:309-314

SAS Institute Inc (1991) SAS/STAT Users Guide. Vol. 2. Version 6. SAS Inst, Cary, NY

Scotney DM, Dijkhuis FJ (1990) Changes in the fertility status of South African soils. S Afr J Plant Soil 86:395-402

Scott VJ, Conyers MK, Poile GJ, Cullis BR (1997) Subsurface acidity and liming affect yield of cereals. Aust J Agric Res 48:843-854

Smith CW, Johnston MA, Lorentz S (1997) Assessing the compaction susceptibility of South African forestry soils. I. The effect of soil type, water content and applied pressure on uni-axial compaction. Soil Till Res 41:53-73

Snedecor GW, Cochran G (1980) Statistical methods, 7th edn. Iowa State University Press, Ames, Iowa, USA

Soane BD, van Ouwerkerk C (1994) Soil compaction in crop production. Elsevier Science B.V, Amsterdam, The Netherlands, p. 662

Soil Classification Working Group (1991) Soil classification: a taxonomic system for South Africa. Memoirs on the agricultural natural resources of South Africa no. 15. Dept. of Agric. Dev, Pretoria, South Africa

Stats SA (Statistics South Africa) (2016) Fact sheets: SA fast facts. South African Government, Pretoria

Swan T, Kirkegaard J, Angus J, Peoples M, Conyers M, Oates A, Poile G, Moroni S (2011) Potential impacts of subsoil constraints on canola productivity in southern NSW. 17th Australian Research Assembly on Brassicas (ARAB) CSIRO Plant Industry, Canberra, \& Wagga Wagga Agricultural Institute, Wagga Wagga, Australia

Tabatabai MA (1994) Soil enzymes. In: Weaver RW, Angle JS, Bottomley PS (eds) Methods of soil analysis, part 2. Microbiological and biochemical properties. Soil Science Society of America, Madison, Wisconsin, pp. 775-833

Tanner PD, Roper CB, De Villiers JM (1986) Effects of soil compaction on pasture growth during rehabilitation of strip-mined land. J Grassl Soc S Afr 3:141-147

The Non-Affiliated Soil Analysis Work Committee (1990) Handbook of standard soil testing methods for advisory purposes. The Soil Science Society of the Republic of South Africa, Pretoria, South Africa

Thompson JD (1986) Sodicity phenomena in red sesquioxic clay subsoils. S Afr J Plant Soil 3(4):189-192

Van Antwerpen R, Meyer JH (1996) Soil degradation under sugar cane cultivation in northern KwaZulu-Natal. Proc S Afr Sugar Technol Assoc 70:29-33 
Van Antwerpen R, Lyne PWL, Meyer E, Brouwers M (2008) Effect of surface applied pressure on properties of a virgin soil. Proc S Afr Sugar Technol Assoc 81:408-417

Van den Berg L, Van Veenhuizen R (2005) Multiple functions of urban agriculture. Urban Agric Magazine 15:1-3

Van Huyssteen L (1988) Soil preparation and grapevine root distributionA qualitative and quantitative assessment. In: The Grapevine Root and its Environment. Technical Communication No. 215, Department of Agriculture \& Water Supply, Pretoria, pp 1-7

Vance ED, Brookes PC, Jenkinson DS (1987) An extraction method for measuring microbial biomass C. Soil Biol Biochem 19:703-707
Walt MM (1991) Amelioration of subsoil acidity by application of a coalderived Calium fulvate to the soil surface. Nature 350:146-148

Yoder RE (1936) A direct method of aggregate analysis of soils and a study of the physical nature of erosion losses. Agron J 28:337-351

Yunusa IAM, Newton PJ (2003) Plants for amelioration of subsoil constraints and hydrological control: the primer-plant concept. Plant Soil 257:261-281

Zhang H, Turner NC, Poole ML, Simpson N (2006) Crop production in the high rainfall zones of southern Australia-potential, constraints and opportunities. Aust J Expt Agric 46:1035-1049 